\title{
Leprosy in children: correlation of clinical, histopathological, bacteriological and immunological parameters
}

\author{
V N SEHGAL* \& JOGINDER \\ Department of Dermatology and Venereology, Maulana Azad \\ Medical College and Associated LNJPN and GB Pant Hospitals, \\ New Delhi, India
}

Accepted for publication 3 March 1989

\begin{abstract}
Summary The study of leprosy in children has indicated an incidence of $10 \%$ amongst leprosy patients attending the clinic. The duration of the disease was usually less than 2 years. The expression of leprosy in this group was either a macule and/or a plaque. Classification was, therefore, different and conforms to indeterminate (I), borderline tuberculoid (BT) and borderline (BB) leprosy. Only occasionally were other clinical variants seen. The bacteriology was largely unproductive by slit-skin smears. The lepromin (Mitsuda) responses were positive in BT and unpredictable in BB patients. Epicutaneous responses to sensitization with dinitrochlorobenzene (DNCB) paralleled responses to lepromin. Microscopic pathology was of very little help. The correlation of these parameters was only $50-60 \%$ indicating that the diagnosis of leprosy should primarily be based on clinical features.
\end{abstract}

\section{Introduction}

Leprosy is a well-conceived entity in children. ${ }^{13}$ The reports ${ }^{3}$ of ever increasing numbers of children afflicted with the disease reflect that a sizeable population in certain vulnerable areas has an age at onset of leprosy between the ages $0-14$ years. In India about $15 \%$ of cases belong to this age group. ${ }^{4}$ It is generally believed that indeterminate, tuberculoid tuberculoid (TT), borderline tuberculoid (BT), and borderline borderline (BB) groups are frequently recorded amongst children, ${ }^{5} 7$ whereas borderline lepromatous (BL) and lepromatous lepromatous (LL) are only occasionally encountered. This appears to be a paradoxical situation in children and runs counter to the concept that 'immune responses' are either negligible or poorly developed in young children. ${ }^{8}$ Hence it is worthwhile to comprehend this phenomenon through clinical, bacteriological, histopathological and immunological parameters as prescribed by Ridley \& Jopling. ${ }^{9}$

* Correspondence: A/6, Panchwati, Opposite Azadpur Subzimandi, Delhi-110 033, India. 


\section{Patients and methods}

Twenty-five children were amongst a total of 250 fresh leprosy patients attending the Urban Leprosy Centre of our Institution, during the National Leprosy Eradication Programme from August 1987 to July 1988. They were classified on the Ridley \& Jopling scale ${ }^{9}$ with some modifications. ${ }^{10}$ They were subjected to skin biopsy for histopathological study. Slit-skin smear examination was done to determine bacteriological status.

Lepromin test was done using $0 \cdot 1 \mathrm{ml}$ of lepromin A containing 40 million bacilli per $\mathrm{ml}$. The early (Fernandez) response was read after 48 hours and the late (Mitsuda) after 4 weeks. The Fernadez response was graded as negative, doubtful $( \pm), 1+, 2+, 3+$ depending upon reaction sizes of less than $5 \mathrm{~mm}, 5-10 \mathrm{~mm}, 10-15 \mathrm{~mm}, 15-20 \mathrm{~mm}$ or more than $20 \mathrm{~mm}$ respectively. The Mitsuda response was graded as negative, doubtful $( \pm), 1+, 2+$ or $3+$ depending upon reaction sizes of $0,1-3 \mathrm{~mm}, 4-6 \mathrm{~mm}, 7-10 \mathrm{~mm}$, or more than $10 \mathrm{~mm}$, respectively.

DNCB (Epicutaneous sensitization with dinitrochlorobenzene) testing was done according to WHO. ${ }^{11}$ DNCB solution in acetone was used in 2 strengths - a sensitizer dose of $2000 \mu \mathrm{g}$ and a challenge dose of $50 \mu \mathrm{g}$. Solutions were placed on the skin through firmly held steel rings above and below the cubital fossa. In the absence of a reaction at 15 days, a rechallenge with $50 \mu \mathrm{g}$ was given in a similar way and test read after $48 \mathrm{hr}$. The response was graded as negative, $1+, 2+, 3+$ or $4+$. Twelve age- and sex-matched healthy children formed controls.

\section{Observations}

Children comprised about $10 \%$ of the leprosy cases diagnosed over a 12-month period in our Institute. Their distribution according to age and sex is shown in Table 1 . The mean age was $10 \cdot 6$ years, while the duration of the disease varied from 2 months to 10 years, with a mean of 1.8 years. The majority $(84 \%)$ of them had a disease duration of less than 2 years. Sixteen of them had borderline tuberculoid (BT) and 6 borderline borderline (BB) leprosy. The three other patients were classified as borderline lepromatous (BL), indeterminate (I) and polyneuritic (P) leprosy. Macules occurred in 14 children and plaques in 5 children. Both the lesions were present in the other 5 children. Well-formed granulomas in tissue sections were seen in 13 children, whereas a scattered infiltrate comprising lymphocytes and histiocytes was seen in the rest. In the single case of BL, acidfast bacilli on slit-skin smear examination were demonstrated (Table 2).

Fernandez response was doubtful $( \pm)$ in 3 borderline tuberculoid and 1 borderline borderline whereas it was negative in rest of them.

It is apparent from Table 2 that the late (Mitsuda) reaction depicted varying positivity from BT to BB leprosy. Moreover, there was no difference in sensitization with DNCB in the BT group and

Table 1. Age and sex distribution

\begin{tabular}{lccccc}
\hline & \multicolumn{2}{c}{ Males } & & \multicolumn{2}{c}{ Females } \\
\cline { 2 - 3 } \cline { 5 - 6 } $\begin{array}{l}\text { Age group } \\
\text { (Years) }\end{array}$ & $\begin{array}{l}\text { No. of } \\
\text { cases }\end{array}$ & $\%$ & & $\begin{array}{l}\text { No. of } \\
\text { cases }\end{array}$ & $\%$ \\
\hline $0-5$ & 1 & $6 \cdot 25$ & & $11 \cdot 11$ \\
$6-10$ & 5 & $31 \cdot 25$ & & $33 \cdot 33$ \\
$11-14$ & 10 & $62 \cdot 25$ & & $55 \cdot 55$ \\
\hline & 16 & $100 \cdot 00$ & 9 & $100 \cdot 00$ \\
\hline
\end{tabular}


Table 2. Correlation of various parameters

\begin{tabular}{lcccc}
\hline & $\begin{array}{c}\text { Clinical } \\
\text { No. }\end{array}$ & $\begin{array}{c}\text { Histopatho- } \\
\text { logical }\end{array}$ & $\begin{array}{c}\text { Bacterial } \\
\text { index }\end{array}$ & $\begin{array}{c}\text { Lepromin } \\
\text { (Mitsuda) }\end{array}$ \\
\hline 5 & BT & BT & 0 & $1+$ \\
3 & BT & BT & 0 & $2+$ \\
1 & BT & BT & 0 & $3+$ \\
3 & BT & NS & 0 & $1+$ \\
2 & BT & NS & 0 & $2+$ \\
1 & BT & NS & 0 & \pm \\
3 & BB & BB & 0 & \pm \\
2 & BB & NS & 0 & $1+$ \\
1 & BB & NS & 0 & \pm \\
1 & BL & BL & $5+$ & \pm \\
\hline
\end{tabular}

NS, non-specific

Table 3. Response to DNCB

\begin{tabular}{lrrrrrr}
\hline & & \multicolumn{5}{c}{ Grading of response } \\
\cline { 3 - 7 } $\begin{array}{l}\text { Leprosy } \\
\text { groups }\end{array}$ & No. & - & $1+$ & $2+$ & $3+$ & $4+$ \\
\hline BT & 16 & 1 & 3 & 5 & 2 & 5 \\
BB & 6 & 3 & - & 2 & - & 1 \\
BL & 1 & 1 & - & - & - & - \\
I & 1 & - & - & 1 & - & - \\
P & 1 & - & - & 1 & - & - \\
\hline Total & 25 & 5 & 3 & 9 & 2 & 6 \\
Controls & 12 & 1 & 1 & 2 & 4 & 4 \\
\hline
\end{tabular}

Table 4. Correlation of lepromin (Mitsuda) and DNCB response

\begin{tabular}{lrrrrrr}
\hline & \multicolumn{5}{c}{ DNCB response } \\
\cline { 3 - 7 } $\begin{array}{l}\text { Lepromin } \\
\text { response }\end{array}$ & No. & - & $1+$ & $2+$ & $3+$ & $4+$ \\
\hline- & 0 & - & - & - & - & - \\
\pm & 6 & 4 & - & 2 & - & - \\
$1+$ & 11 & 1 & 1 & 4 & - & 5 \\
$2+$ & 7 & - & 1 & 3 & 2 & 1 \\
$3+$ & 1 & - & 1 & - & - & - \\
\hline
\end{tabular}

controls (Table 3 ). In the BB group, on the other hand, only three children could be sensitized-a response which is significantly poor when compared to BT and controls. $(p<0 \cdot 05)$. The correlation between lepromin (Mitsuda) and DNCB sensitization is shown in Table 4. The correlation of various parameters namely clinical, histopathological, bacteriological and lepromin (Mitsuda) is shown in Table 2. It is evident that a clinical-histopathological correlation was seen in 9 BT, 3 BB and $1 \mathrm{BL}$ patient. 


\section{Discussion}

It is well-established that children are more susceptible to acquiring leprosy than adults. ${ }^{2}$ However, the spectrum of the disease among them is different. It is characterized by macules and/or plaques present more often on exposed areas. ${ }^{7}$ Macule is a predominant lesion. Accordingly, the histopathology also reflects a non-specific picture in a large number of patients. This aspect has been well-documented in our study. As the formation of a granuloma is indicative of eff ective build up of immunity, ${ }^{13}$ it follows that in children immunity was not as effective as in adults.

The Fernandez response to lepromin indicates a pre-existing hypersensitivity to either M. leprae or other cross-reacting Mycobacteria. ${ }^{14}$ It appears that negative or doubtful responses in children could be due to inadequate pre-exposure to such organisms or to the inability of the immune system to respond to such exposure. The response pattern of the Mitsuda reaction was almost similar to that of adults in our study. A positive response in the indeterminate and the polyneuritic patients indicates their place nearer to the tuberculoid end of the spectrum. The impairment of DNCB responses in conformity with negative or doubtful Mitsuda reactions in BB and BL leprosy indicates the parallel impedement of specific and non-specific CMI.

A correlation of various parameters namely clinical, histopathological and lepromin (Mitsuda) responses was seen in only $56 \cdot 7 \%$ of BT children. In the clinically BB group only $50 \%$ conformed to the histopathological picture of BB. Moreover, slit-skin smears failed to demonstrate acid-fast bacilli in any of them. Such discordance among various parameters has earlier been reported. ${ }^{15}{ }^{18}$ In one double-blind study, ${ }^{15}$ such correlation was found to be only $44 \%$. Our study, therefore, reiterates that clinical criteria should be the mainstay in the diagnosis of leprosy in children.

\section{References}

1 Cochrane RG. A practical text book of Leprosy, London: Oxf ord University Press, 1947.

2 Saul A. Early signs of leprosy in children. Modern Problems in Paediatrics 1978; 20: 142-50.

${ }^{3}$ Sehgal VN, Rege VL, Mascarenhas MF et al. The prevalence and pattern of leprosy in a school survey. Int $J$ Lepr, 1977; 45: 360-3.

${ }^{4}$ Anonymous, Ministry of Health \& Family Welfare, Government of India (1982) Annual Report 1981-82, New Delhi.

${ }^{5}$ Sehgal VN, Sehgal S. Leprosy in young urban children. Int J Derm, 1988; 27: 112-14.

${ }^{6}$ Dave DS, Agarwal SK. Prevalence of Leprosy in children of leprosy patients. Ind J Lepr, 1984; 56: 615-21.

${ }^{7}$ Sehgal VN, Srivastava G. Leprosy in children, Int J Derm, 1987; 26: 557-66.

8. Cruikshank R, Duguid JP, Marmian BP, Swain RHA (eds). Medical microbiology: natural and acquired immunity. ELBS ed. 1973; pp 134-63.

9 Ridley DS, Jopling WH. Classification of leprosy according to immunity. A five group system. Int J Lepr, 1966; 34: 255-73.

${ }^{10}$ Sehgal VN. Seven group classification of leprosy for institutional and field work (Letters). Lepr Rev, 1989; 60: 75.

11 Anonymous. WHO Handbook of Immunological Techniques. Geneva. 1979. pp 1.5.

12 Dharmendra. Notes on leprosy: epidemiology of leprosy. Ministry of Health, Government of India, New Delhi. 1960; pp 83-92.

${ }^{13}$ Robbins SL, Kumar V. Basic pathology: inflammation and repair. Philadelphia: SB Saunders Company (Publ). 1987; pp 28-61.

${ }^{14}$ Harboe M. Immunology of leprosy. In Hastings RC, (ed.): Leprosy Churchill Livingstone (Publ.) 1985; 5387.

${ }^{15}$ Sehgal VN, Koranne RV, Sehgal S, Beohar PC, Sharma VK. Correlation of morphological, bacteriological, histopathological and immunological features of leprosy. A double blind study. J Derm (Tokyo), 1985; 45: 278-80.

${ }^{16}$ Meyer WM, Heggie CD, Kay TL, Staple EM \& Kver Nes S. The Ridley-Jopling five group classification of leprosy. Correlation of the classification in 1429 leprosy patients. Int J Lepr, 1979; 47: 683-4.

${ }^{17}$ Sehgal VN, Rege VL, Rays M. Correlation between clinical, bacteriological and histopathological classification of leprosy. Int J Lepr, 1977; 45: 278-80.

${ }^{18}$ Sehgal VN, Koranne RV, Nayyar M, Saxena HMK. Application of clinical \& histopathological classification of leprosy. Dermatologica, 1980; 161: 93-6. 